\title{
Responses of basophilic cells of the digestive gland of mussels to petroleum hydrocarbon exposure
}

\author{
Miren P. Cajaraville, Guzmán Díez, Ion A. Marigómez, Eduardo Angulo
}

Zitologi eta Histologi Laborategia, Biologia Zelularra eta Zientzia Morfologikoen Saila, Zientzi Fakultatea, Euskal Herriko Unibertsitatea, 644 P.K., E-48080 Bilbo, Spain

\begin{abstract}
A stereological study was conducted on the digestive gland of mussels Mytilus galloprovincialis Lmk., exposed to the water accomodated fraction of 2 crude oils and a commercial lubricant oil (3 different concentrations of each). Mussels were sampled after 21,35, 77 and $91 \mathrm{~d}$ exposures, and the volume density (VD) of basophilic cells was determined in paraffin sections by a point-counting method. Exposure to petroleum hydrocarbons resulted in a significant dose-dependent increase in basophilic cell volume density. This was due to the presence of higher numbers of basophilic cells per digestive tubule, while the size of basophilic cells remained apparently unchanged. Results are interpreted in terms of an enhanced epithelial cell regeneration that might be linked to fundamental digestive processes. Indeed, a significant positive linear correlation exists between basophilic cell VD and the percentage of disintegrating tubules.
\end{abstract}

\section{INTRODUCTION}

The digestive diverticula of bivalves consist of numerous blind-ending tubules which communicate with the stomach by way of partially ciliated main ducts and non-ciliated secondary ducts (Owen 1970). The light microscope reveals that digestive and basophilic cells comprise the epithelium which lines the digestive tubules. Digestive cells are responsible for the intracellular digestion of food material while basophilic cells are thought to be involved in the synthesis and secretion of enzymes for extracellular digestion (Owen 1972). Early observations by Owen (1970) on the ultrastructure of the digestive tubules of Cardium edule revealed 2 different types of basophilic cells: pyramidal cells rich in granular endoplasmic reticulum and flagellated columnar cells. The later are considered to be immature and may serve to replace either the pyramidal basophilic cells, or the digestive cells, or both (Owen 1970). A similar cell type has been described in Mytilus edulis, held in the laboratory for long periods by Thompson et al. (1974), who suggest that the flagellate cell may differentiate into a mature digestive cell under suitable conditions.

Changes in molluscan digestive tubule structure due to pollutants have been studied quantitatively by Lowe et al. (1981), Tripp et al. (1984), Marigómez et al. (1986), Axiak et al. (1988), Recio et al. (1988) and Vega et al. (1989). Special attention was paid to the effects of pollutants on the structure and function of digestive cells since their lysosomal system is involved in hydrocarbon uptake (Moore 1980) and shows a high degree of responsiveness to alterations in the environment (Lowe et al. 1981, Harrison \& Berger 1982, Moore et al. 1987, Cajaraville et al. 1989b, Marigómez et al. 1989). However, recent studies clearly suggest that basophilic cells are also subjected to important alterations under stress conditions. Petroleum hydrocarbon exposure induces the accumulation of large quantities of lipids in basophilic cells of mussels together with the fragmentation and vacuolation of cisterns of the rough endoplasmic reticulum and Golgi bodies (Carles et al. 1986, Lowe 1988). Further, Rasmussen et al. (1983) note that 'chronic' treatment of mussels with a $\mathrm{N}$-nitroso compound causes varying degrees of degeneration in cells comprising the digestive epithelium, and that some digestive tubules are only composed of basophilic cells exhibiting dilatation and condensation of the endoplasmic reticulum. Widdows et al. (1984) found that exposure to petroleum hydrocarbons causes an 'apparent' increase in the numbers of basophilic cells in the prosobranch gastropod Littorina littorea while they do not report similar changes in Mytilus edulis maintained under the same conditions. An increased occurrence of basophilic cells has also been reported by us to occur in L. littorea under experimentally induced stress 
conditions (Cajaraville et al. 1990, Marigómez et al. 1990). However, none of the studies mentioned above have applied quantitative techniques to measure changes in basophilic cell size or numbers; thus, the question of whether altered environmental conditions cause an increased presence of basophilic cells in molluscan digestive gland remains unanswered.

The purpose of the present study is to quantify the volume density of basophilic cells of the digestive gland of Mytilus galloprovincialis by using a stereological method and to describe the effects of the exposure to the Water Accomodated Fraction (WAF) of 3 different petroleum-derived hydrocarbons (PHC) on the basophilic cell volume.

\section{MATERIAL AND METHODS}

Experimental procedure. Mussels, collected from Meñakoz, Biscay, Spain (43⒉ $4^{\prime}$ N, $2^{\circ} 93^{\prime}$ W) in March 1988 , were transferred to the laboratory. Fifty individuals ( 2.5 to $3.5 \mathrm{~cm}$ shell length) were distributed in 251 polyethylene-covered tanks in a thermostatized semicontinuous water-flow system with activated charcoal and glass-wool filtered natural seawater (Zierbena, Biscay). Mussels were maintained unfed at 15 to $16{ }^{\circ} \mathrm{C}$ for $10 \mathrm{~d}$ to facilitate acclimatization to laboratory conditions. Subsequently, individuals were exposed in replicated series for 3 mo to different dilutions of the WAF of 2 crude oils (Maya and Ural types, supplied by Petronor SA, Spain), and a commercial lubricant oil (Repsol HD, made by Repsol SA, Spain).

The WAF of the oils was prepared using methods of Boylan \& Tripp (1971) and Anderson et al. (1974). Oil $(800 \mathrm{ml})$ was placed over 9 to $10 \mathrm{l}$ seawater in a 15 I Mariotte glass bottle with a rubber stopper and stirred with a magnetic stirrer for $12 \mathrm{~h}$ at room temperature, 18 to $20^{\circ} \mathrm{C}$. Stirring speed was adjusted to prevent the vortex of the mixture from extending more than $25 \%$ of the mixture's height from the surface. WAF from each oil was produced twice every day. After separaton of oil and water phases, the aqueous phase (100\% WAF) was siphoned off and poured directly into sea water in the aquaria daily to obtain the following test categories: $0.6 \%$ (low dose, LD), $6 \%$ (intermediate dose, ID), and $40 \%$ (high dose, HD) dilutions of the different WAFs. We replaced $100 \%$ of the water every $2 \mathrm{~d}$ and carried out 1 replicate control set.

Mussels were maintained under natural photoperiods and fed with a commercial filter-feeder food (Marne Invertebrate Diet, Hawaiian Marine Imports inc., distributed by Carolina Ltd.) during the experimental period. Tanks were continuously aerated and water temperature, recorded every working day, averaged $15.25 \pm 1.01^{\circ} \mathrm{C}$ in April, $16.17 \pm 0.77^{\circ} \mathrm{C}$ in May and $16.47 \pm 1.20^{\circ} \mathrm{C}$ in June.

Stereological analysis of basophilic cells. Mussels were sampled following 21,35, 77 and $91 \mathrm{~d}$ exposures. Five mussels were removed from each replicate experimental group at each sampling period. After mussel removal from the shcll, a portion of the mantle-digestive gland tissue was carefully excised and fixed in Bouin's fluid. Following dehydration through an ascending ethanol series, tissues were cleared in methylbenzoate and embedded in paraffin. Sections $(9 \mu \mathrm{m})$ were cut and stained by haematoxylin and eosin $(\mathrm{H} \& \mathrm{E})$.

A stereological procedure was applied in order to quantify the volume density of basophilic cells. Counts were made in each of 5 fields of 2 different sections ( 45 to $180 \mu \mathrm{m}$ distance) of the digestive gland. Within a given section fields were selected by always starting at the top-right angle of the tissue. Further fields were selected at given intervals across the tissue section, the direction of movement always following a zig-zag pattern. Thus, cell counts were made in 10 fields per mussel $(10 \times 10=100$ counts per experimental group) using a drawing-tube attachment to a Nikon Optiphot microscope (total magnification $670 \times$ ). A Weibel graticule (multipurpose test system $M-168$; Weibel 1979) was used, and hits on basophilic cells and on remaining digestive tissue were recorded. From these values the volume density (VD) of basophilic cells was determined using the following equation:

$$
\mathrm{VD}=\frac{\mathrm{X} 1+\mathrm{X} 2+\ldots+\mathrm{Xn}}{\mathrm{m} \times \mathrm{n}}
$$

where $\mathrm{X}=$ number of segment edges falling on basophilic cells; $m=$ total number of segment edges falling on digestive tissue; $n=$ number of counts ( 10 for each mussel).

Statistics. The statistical packet SPSS/PC+ (SPSS Inc., Microsoft Co.) was used in an AT personal computer (Atlas 286). Confidence intervals were calculated using Student's t-test and significant differences between means were established at the $p<0.05$ level (Sokal \& Rohlf 1979). Significance of results was tested using a 3 -way analysis of variance (ANOVA) to detect the effects of the factors studied (exposure-concentration, exposure-time, type of toxicant) on the VD of basophilic cells. Correlation and regression analyses were also carried out to establish significant relationships between basophilic cell VD and the above mentioned factors. In addition, correlation analyses were performed to establish significant correlations between changes in basophilic cell VD and changes in the percentages of the different digestive tubule types. For this purpose, digestive tubules were analysed using a subjective tubule grading method (Cajaraville et al. 1989a) where tubules were classified, according to 
Langton (1975) into holding, absorbing, disintegrating and reconstituting. A 5th tubule type was considered necrotic (Cajaraville et al. 1989a).

\section{RESULTS}

Basophilic cells of Mytilus galloprovincialis can easily be distinguished from digestive cells in $\mathrm{H}$ \& E stained sections under the light microscope (Fig. 1). Volume density (VD) of basophilic cells did not change in control mussels through the experimental period, except on Sampling day 35 where the value dropped markedly (Fig. 2).
The exposure to WAF of the 3 different PHC causes an increase in the VD of basophilic cells (Fig. 2). The response is observed in mussels exposed to ID and HD of the 3 PHC types tested and, with some exceptions, a dose-dependent effect is recorded. Values of mussels exposed to LD of Maya and Ural crude-oil types are not different from control values, while individuals exposed to LD of lubricant oil respond after $49 \mathrm{~d}$ exposure. VD values corresponding to HD of refined oil are missing on Sampling days 77 and 91 since mussels subjected to this treatment died after $49 \mathrm{~d}$ exposure. We recorded $100 \%$ mortality also in one of the ID series after $77 \mathrm{~d}$ exposure. Non-significant mortalities were noted during the whole experimental period in
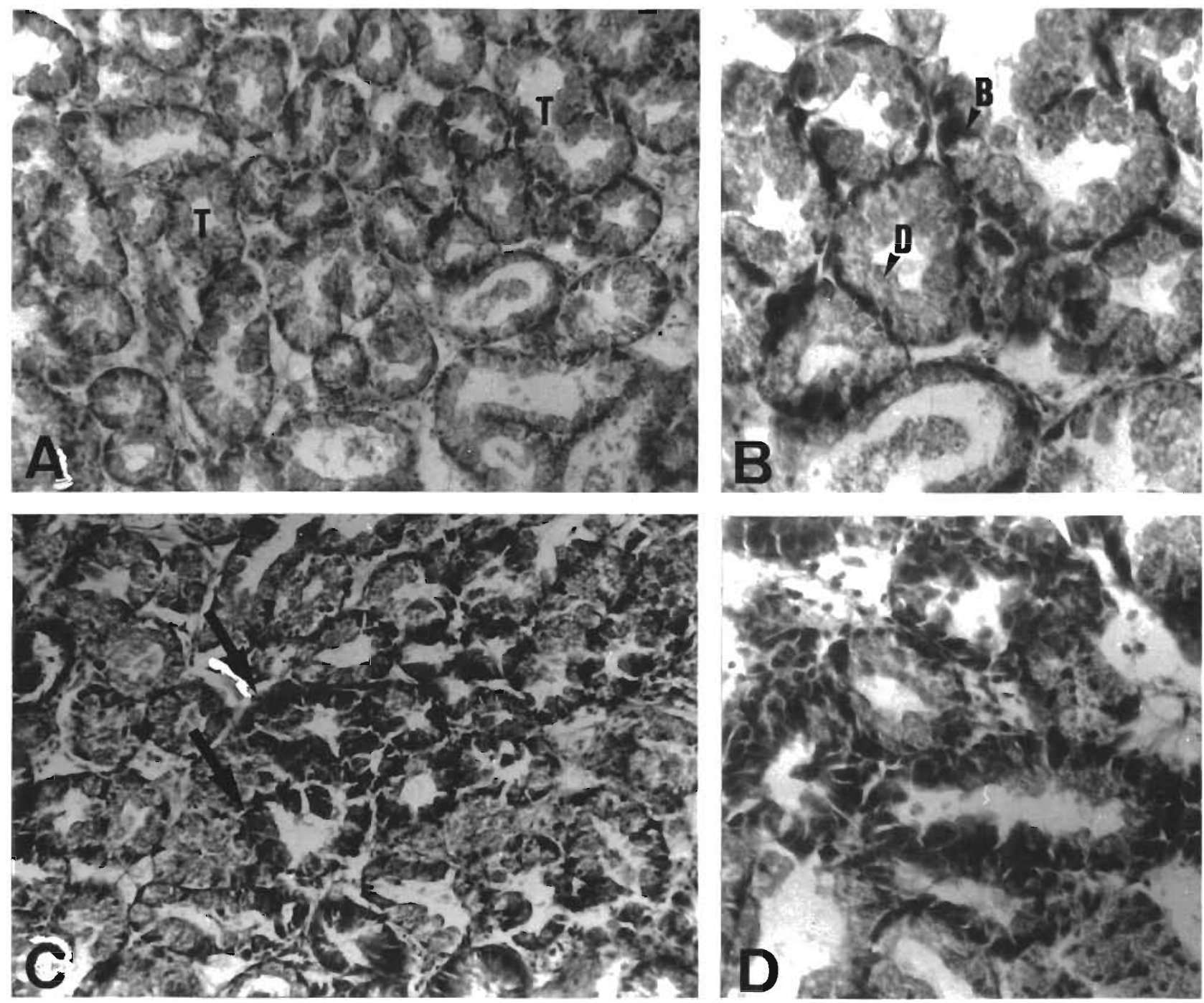

Fig. 1. Mytilus galloprovincialis. (A) Paraffin section of the digestive gland of a control individual sampled after $91 \mathrm{~d}$ maintenance in the laboratory; H \& E $200 \times$. (B) Higher magnification of the digestive tubules of the same individual; H \& E 400X (C) Paraffin section of the digestive gland of a mussel exposed for $91 \mathrm{~d}$ to the ID of the WAF of lubricant oil. Note that some tubules are comprised mostly of basophilic cells (arrows); H \& E 200x (D) Higher magnification of digestive tubules of the same individual;

$\mathrm{H} \& \mathrm{E} 400 \times$. T: digestive tubule, D: digestive cell, B: basophilic cell 
mussels exposed to any dose of the 2 crude oils tested. In mussels treated with Maya, no mortalities occurred at LD, 1 mussel died after 21 d exposure to ID, and 4 died at $\mathrm{HD}$ (Days 50,69,70 and 74). In mussels treated with Ural, 1 individual died at LD (Day 79), 5 at ID (Days 37, 49, 71, 72 and 79) and 0 at HD.

Considering changes in VD of basophilic cells over the experimental period in the different treatments revealed that the lower values occurred on the 35th sampling day (as in the controls). Differences between control and treated mussels were always evident for each sampling period.

The most pronounced increase in basophilic cell VD
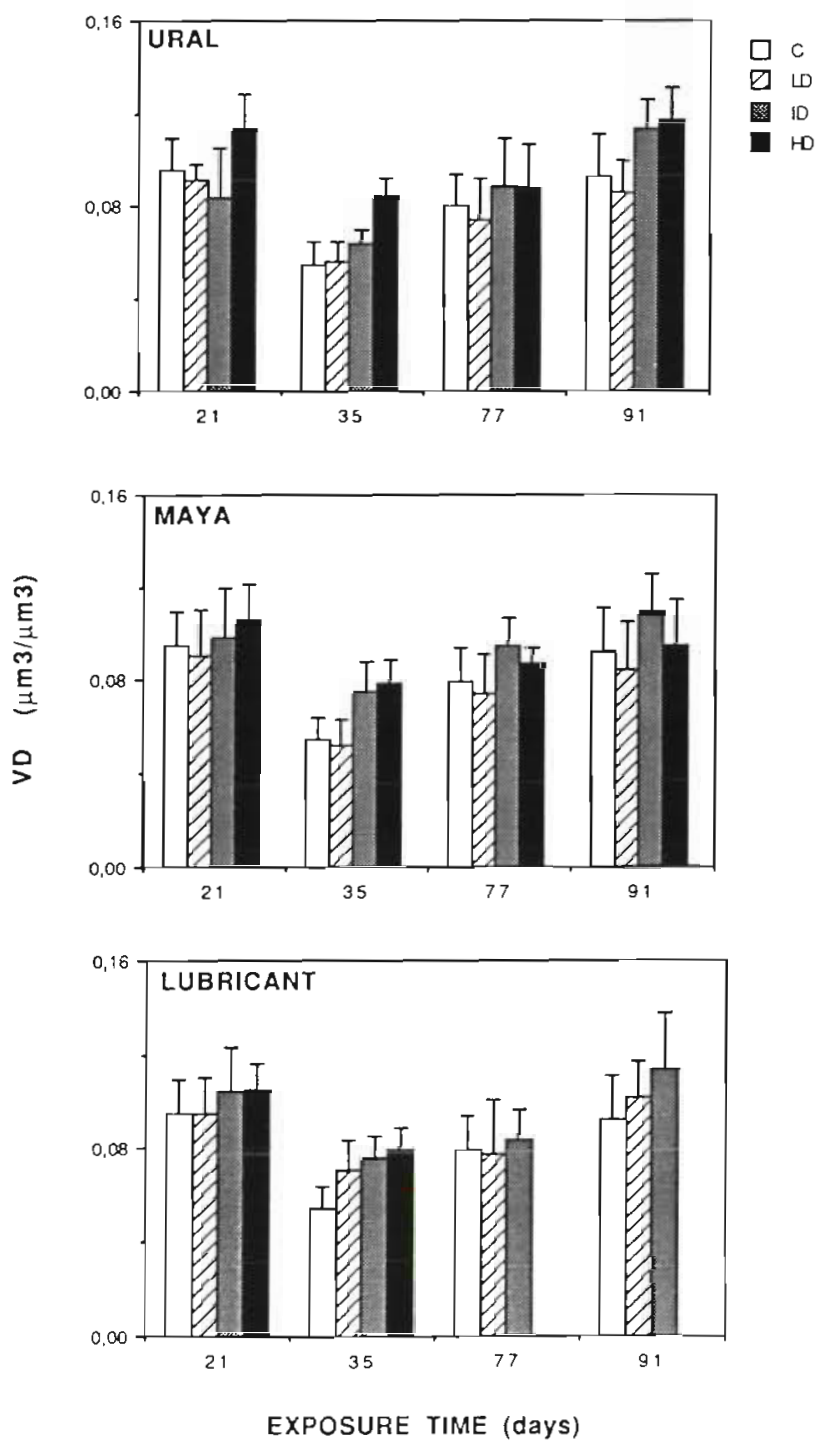

Fig. 2. Mytilus galloprovincialis. Results of stereological analyses of basophilic cells in digestive glands following exposure to WAF of Ural-type crude oil, of Maya-type crude oil, and of lubricant oil. VD: volume density of basophilic cells $\left(\mu^{3}\right.$ $\left.\mathrm{um}^{-3}\right)_{\mathrm{i}} \mathrm{C}$ : control; LD: low dose; ID: intermediate dose; HD: high dose. Vertical segments: $95 \%$ confidence intervals was recorded in mussels treated with $\mathrm{HD}$ of the Uraltype crude oil after 21, 35 and 91 d exposure (19.13, 54.67 and $26.45 \%$ increase over control values from the respective sampling periods). An increase in the size of individual basophilic cells was not apparent in treated individuals. The increased VD recorded in PHC-exposed mussels is thus believed to be due to increased numbers of basophilic cells per digestive tubule (Fig. 1C, D). This was not observed in all digestive tubules of treated individuals, the response being limited to a number of tubules distributed through the whole digestive gland. This response pattern is the cause of the high variability found in stereological analyses between different fields within the same individual.

The 3 -way analysis of variance (Table 1) indicates that there is a significant $(\mathrm{p}<0.0001$ ) effect of exposure time and exposure concentration on this parameter. In contrast, neither the type of PHC used nor the second-and third-order interactions between exposure time, exposure concentration and type of toxicant had a significant effect on the VD of basophilic cells. When interaction terms were suppressed to analyse the pure effect of each factor, the levels of significance remained unchanged. Correlation and regression analyses performed for each type of toxicant separately (Table 2) demonstrate that the VD of basophilic cells (in logits) increases linearly with increasing concentrations (in logits) of the toxicants. It must be stressed that regression coefficients do not vary significantly between types of toxicants as could be expected from ANOVA results. The variable exposure time is only significant in Ural-type crude oil. The regression equation for the total experimental population is similar to that of the Ural-type crude oil (Table 2). The dependent variable,

Table 1 Three-way ANOVA. T: exposure-time, D: exposure concentration, $W$ : type of toxicant. Significance level $=95 \%$

\begin{tabular}{|lrrrrl|}
\hline Source & SS & DF & MS & F & $p$ \\
\hline Main effects & 0.064 & 8 & 0.008 & 22.760 & $<0.0001$ \\
T & 0.048 & 3 & 0.016 & 44.907 & $<0.0001$ \\
D & 0.020 & 3 & 0.007 & 18.769 & $<0.0001$ \\
W & 0.001 & 2 & 0.001 & 1.884 & $>0.1$ \\
-way inter & 0.009 & 21 & 0.0001 & 1.264 & $>0.1$ \\
T $\times$ D & 0.004 & 9 & 0.0001 & 1.336 & $>0.1$ \\
T $\times$ W & 0.002 & 6 & 0.0001 & 0.854 & $>0.5$ \\
D $\times$ W & 0.003 & 6 & 0.001 & 1.591 & $>0.1$ \\
3-way inter & 0.002 & 10 & 0.0002 & 0.439 & $>0.9$ \\
Explained & 0.075 & 39 & 0.002 & 5.462 & $<0.001$ \\
Residual & 0.079 & 223 & 0.0001 & & \\
TOTAL & 0.154 & 262 & 0.001 & & \\
\hline
\end{tabular}


Table 2. Mytilus galloprovincialis. Regression equations of basophilic cell VD (log) against exposure-concentration (D), exposuretime $(\mathrm{T})$ and concentration $\times$ time interaction (with and without logarithmic transformation) for each PHC tested and for the total experimental population. Only independent variables (VAR) with significant regression coefficients $(p<0.05$ according to Student's t-test) shown. K: Y-intercept; $b$ : regression coefficient; $S E(b)$ : standard error of $b$; $p(b)$ : signification of $b$ based on Student's t-test; r multiple correlation coefficient; $\mathrm{p}(\mathrm{r})$ : signification of $\mathrm{r}$ based on Fisher's F-test; df: degrees of freedom

\begin{tabular}{|c|c|c|c|c|c|c|}
\hline $\begin{array}{l}\text { Ural } \\
\text { VAR }\end{array}$ & $\mathrm{b}$ & $\mathrm{SE}(\mathrm{b})$ & $p(b)$ & r & $\mathrm{p}(\mathrm{r})$ & $\mathrm{df}$ \\
\hline $\log D$ & 0.1924 & 0.0543 & 0.0006 & 0.3979 & 0.0001 & 110 \\
\hline $\mathrm{T}$ & 0.0289 & 0.0114 & 0.0125 & & & \\
\hline $\mathrm{K}$ & 0.7671 & 0.0355 & $<0.00005$ & & & \\
\hline \multicolumn{7}{|l|}{ Maỵa } \\
\hline VAR & $\mathrm{b}$ & $\mathrm{SE}(b)$ & $p(b)$ & $r$ & $\mathrm{p}(\mathrm{r})$ & $\mathrm{df}$ \\
\hline $\log D$ & 0.1812 & 0.0538 & 0.0010 & 0.2930 & 0.0010 & 122 \\
\hline $\mathrm{K}$ & 0.8453 & 0.0229 & $<0.00005$ & & & \\
\hline \multicolumn{7}{|c|}{ Lubricant oil } \\
\hline VAR & $\mathrm{b}$ & $\mathrm{SE}(\mathrm{b})$ & $p(b)$ & r & $\mathrm{p}(\mathrm{r})$ & $\mathrm{df}$ \\
\hline $\log D$ & 0.1665 & 0.0591 & 0.0059 & 0.2723 & 0.0059 & 100 \\
\hline $\mathrm{K}$ & 0.8659 & 0.0224 & $<0.00005$ & & & \\
\hline \multicolumn{7}{|l|}{ Total } \\
\hline VAR & $b$ & $\mathrm{SE}(\mathrm{b})$ & $p(b)$ & $\mathrm{r}$ & $p(r)$ & df \\
\hline $\log D$ & 0.1727 & 0.0297 & $<0.00005$ & 0.3258 & $<0.00001$ & 360 \\
\hline $\mathrm{T}$ & 0.0176 & 0.0063 & 0.0057 & & & \\
\hline K & 0.8109 & 0.0190 & $<0.00005$ & & & \\
\hline
\end{tabular}

VD of basophilic cells $(\times 100)$, was log-transformed since regression equations developed with untransformed values showed lower significance of regression coefficients.

Correlation analyses between basophilic cell VD and percentages of each tubule type are shown in Table 3. Both linear and logarithmic correlation coefficients were calculated. Correlation coefficients with the best significance for each pair basophilic cell VD/tubule type percentage have been indicated (Table 3 ). In mussels exposed to the WAF of the Ural-type crude oil, basophilic cell VD increases with increasing percentages of disintegrating tubules and decreasing percentages of absorptive tubules (in logits), while the VD of

Table 3. Mytilus galloprovincialis. Linear and logarithmic correlation coefficients between basophilic cell VD and percentages of each tubule type. B: basophilic cell VD $(\times 100)$; H: holding tubules (\%); A: absorbing tubules $(\%)$; D: disintegrating tubules $(\%)$; $\mathrm{R}$ : reconstituting tubules $(\%) ; \mathrm{N}$ : necrotic tubules $(\%) ; \mathrm{n}$ : sample size. Analyses performed for each toxicant and for total experimental population. Underlined values: best significance of the 4 correlation coefficients calculated for each pair basophilic cell VD/tubule type percentage

\begin{tabular}{|c|c|c|c|c|c|c|c|c|c|c|c|c|}
\hline & \multicolumn{3}{|c|}{ Ural } & \multicolumn{3}{|c|}{ Maya } & \multicolumn{3}{|c|}{ Lubricant oil } & \multicolumn{3}{|c|}{ Total } \\
\hline & B & $\log B$ & $\mathrm{n}$ & B & $\log B$ & $\mathrm{n}$ & B & $\log B$ & $\mathrm{n}$ & B & $\log B$ & $\mathrm{n}$ \\
\hline $\mathrm{H}$ & -0.202 & $-0.241^{\circ}$ & 108 & -0.157 & $-0.224^{\circ}$ & 119 & -0.080 & -0.120 & 95 & $-0.159^{\circ}$ & $-0.210^{\circ}$ & 348 \\
\hline A & -0.198 & -0.155 & 107 & -0.116 & -0.085 & 119 & -0.173 & -0.146 & 98 & $-0.148^{\circ}$ & -0.113 & 350 \\
\hline $\mathrm{D}$ & $\underline{0.364^{\cdots}}$ & $0.339^{\cdots}$ & 111 & 0.190 & 0.192 & 123 & $0.262^{\circ}$ & $0.240^{\circ}$ & 101 & $0.271^{\circ} \cdot$ & $0.254^{\cdots}$ & 361 \\
\hline $\mathrm{R}$ & $\overline{0.069}$ & 0.071 & 109 & 0.086 & 0.096 & 115 & $\overline{0.058}$ & 0.066 & 91 & $\overline{0.066}$ & 0.075 & 339 \\
\hline$N$ & -0.224 & -0.204 & 75 & $-0.293^{\circ}$ & $-0.305^{\circ}$ & 78 & -0.162 & -0.124 & 68 & $-0.223^{\circ}$ & $-0.207^{\cdots}$ & 237 \\
\hline $\log \mathrm{H}$ & -0.198 & $-0.226^{\circ}$ & 108 & -0.169 & $-0.214^{\circ}$ & 119 & -0.031 & -0.064 & 95 & $-0.148^{\circ}$ & $-0.183^{\cdots}$ & 348 \\
\hline $\log A$ & $-0.305^{\cdots}$ & -0.254 & 107 & -0.115 & -0.098 & 119 & -0.129 & -0.124 & 98 & $-0.165^{\circ} \cdot$ & $-0.139^{\circ}$ & 350 \\
\hline $\log D$ & $0.327^{\cdots}$ & $0.306^{\cdots}$ & 111 & 0.192 & 0.185 & 123 & $0.259^{\circ}$ & $0.231^{\circ}$ & 101 & $0.260^{\circ}$ & $0.240^{\circ}$ & 361 \\
\hline $\log \mathrm{R}$ & 0.040 & 0.039 & 109 & 0.082 & 0.081 & 115 & 0.030 & 0.028 & 91 & 0.041 & 0.042 & 339 \\
\hline $\log N$ & -0.220 & -0.196 & 75 & -0.262 & $-0.271^{2}$ & 78 & -0.123 & -0.080 & 68 & $-0.205^{\cdots}$ & $-0.185^{\circ}$ & 237 \\
\hline
\end{tabular}


basophilic cells (in logits) is negatively correlated with the percentage of holding tubules. For mussels exposed to the Maya-type crude oil, VD (in logits) covaries negatively with both the percentage of holding tubules and the percentage of necrotic tubules. For the lubricant oil, basophilic cell VD is positively correlated with the percentage of disintegrating tubules. Taking into account that the ANOVA indicates no significant differences in basophilic cell VD between different $\mathrm{PHC}$, the correlation analysis was performed for the whole experimental population. It then became apparent that basophilic cell VD is correlated positively with the percentage of disintegrating tubules and negatively with the percentage of necrotic tubules and the percentage of absorbing tubules (in logits) Basophilic cell VD (in logits) is also negatively correlated with the percentage of holding tubules. In no case was a significant correlation recorded between basophilic cell VD and percentage of reconstituting tubules.

\section{DISCUSSION}

The volume density of basophilic cells was quantified by stereology in the digestive gland of Mytilus galloprovincialis. Both control and treated mussels showed very low values of basophilic cell VD on the 35th sampling day (early May). An explanation for this phenomenon could be obtained from a parallel study carried out under identical experimental conditions (Cajaraville et al. 1989a). In this study a slight increase in both digestive tubule epithelial thickness and digestive tubule size was recorded in mussels (controls and experimentals) at the 35 th sampling day. These changes could account for a reduced probability of finding basophilic cells in a given microscopic field. Besides, these results seem to be related to the reproductive state of mussels since the lowest values of the gonad index (Seed 1969) occur, especially in females, also in this sampling period (own unpubl. results). Durfort (1989) finds that the progression of the different developmental stages of oocytes is associated with changes in digestive gland Type B cells, involved in calcium storage and mobilisation, in the polyplacophoran mollusc Acanthochitona fascicularis. However seasonal variations in digestive and basophilic cell numbers of digestive tubules and in digestive tubule size have, to our knowledge, never been reported; thus this idea is rather speculative.

Significant alterations were recorded in basophilic cell VD as a result of petroleum hydrocarbon exposure. The 3 different PHCs tested induce a significant increase in basophilic cell VD due to the presence of increased numbers of basophilic cells per digestive tubule. Both hydrocarbon exposure concentration and exposure time exert a significant effect on the VD of basophilic cells. There was no significant interaction between concentration and time, indicating that increased values of the parameter were maintained throughout the experiment without showing any longterm recovery or deterioration. Besides, there was no significant effect of the type of toxicant used (2 different crude oils and 1 lubricant oil) which clearly indicates that the response is independent of the $\mathrm{PHC}$ tested. In fact, the regression analyses carried out separately for each toxicant show that basophilic cell VD increases with increasing exposure concentrations after double logit transformation. This further implies an attenuated slope in the response at lower and higher exposure concentrations, a linear dose dependence being achieved only when mussels were exposed to intermediate concentrations. Nevertheless, although the 3 PHCs evoked a similar response pattern in basophilic cells it is evident that the lubricant oil is much more toxic to mussels since it is the only toxicant causing significant mortality. It is also the only toxicant inducing an increase in basophilic cell VD at the low exposure dose. In other studies, WAF of refined oils was reported to be more toxic than WAF of crude oils (Anderson et al. 1974, Rice et al. 1976).

Widdows et al. (1984) found an apparent increase in the number of basophilic cells in Littorina littorea exposed to petroleum hydrocarbons, while a $2.5 \mathrm{~d}$ recovery was sufficient to cause a reduction in basophilic cell numbers. Since an increased incidence of basophilic cells has also been suggested in studies concerning 1 -naphthol and cadmium toxicities in $L$. Iittorea (Cajaraville et al. 1990, Marigómez et al. 1990), it could be hypothesized that the response is general among molluscs and independent of the stressor involved. These characteristics, together with the above-reported significant dose-dependent effect, could allow a potential use of VD of basophilic cells as a general stress indicator in marine pollution-monitoring programs. Furthermore, quite distinct stress sources such as crowding of the larval stages of Schistosoma japonicum in the intertubular spaces of the digestive gland of the gastropod Oncomelania hupensis quadrasi resulted in a marked increase of pyramidal calcium cells (possibly equivalent to bivalve basophilic cells) together with vacuolation of digestive cells (Querubin \& Enriquez 1989). This again seems to indicate that basophilic cells of molluscan digestive tissue respond to a variety of harmful conditions by increasing their numbers and that this response is usually associated with degenerative changes in digestive cells (Thompson et al. 1974, Rasmussen et al. 1983, Querubin \& Enriquez 1989, Cajaraville et al. 1990, Marigómez et al 1990). Whether increased numbers of basophilic cells are simply due to concomitant reduction in digestive 
cell numbers or whether basophilic cell proliferation is a necessary step for digestive cell regeneration remains to be investigated. Studies by Mix \& Sparks (1971) and Thompson et al. (1974) suggest that replacement of digestive cells occurs by division of (a type of) basophilic cell. Thus, proliferation of basophilic cells could be related to an increased loss of digestive cells which would require an increased cell turnover and regeneration in damaged digestive tubules.

In context with this hypothesis, an interesting question is whether different tubular types (see Langton 1975 for a description of phasic types of digestive tubules) bear different numbers of basophilic cells. Preliminary results (present paper) indicate that high values of basophilic cell VD occur when the percentage of disintegrating tubules in a given digestive gland is also high (and subsequently, percentages of holding, absorbing and necrotic tubules are low). In no case was the basophilic cell VD significantly correlated with the percentage of reconstituting tubules. Thus, changes in basophilic cell numbers could be associated with phasic activities of the digestive gland and consequently, to both digestion process and turnover of digestive cells. Widdows et al. (1984) consider the PHC-induced increase in basophilic cell numbers to be an adaptative response in order to meet the increased demands on the digestive secretory system resulting from the presence of oil. In conditions in which digestive cells are challenged, and thus the intracellular digestion process is affected, an increase in basophilic cell numbers might be necessary to augment enzyme secretion for extracellular digestion (Marigómez et al. 1990), This again suggests that alterations in basophilic cell incidence could be related to fundamental digestive cell processes.

More information is needed on both the role of basophilic cells in bivalve digestive gland physiology and the reactions of these cells to the presence of environmental PHC. At the cellular level, fragmentation and vacuolation of the rough endoplasmic reticulum, dilation of the Golgi apparatus (Carles et al. 1986) and accumulation of lipid droplets (Carles et al. 1986, Lowe 1988) occur. Whether these alterations in basophilic cells are a consequence of hydrocarbon metabolism and detoxification is not known. Triebskorn (1989) suggests a potential involvement of calcium cells of terrestrial slugs in the metabolism of carbamates and metaldehyde since an intensified activity of NADPH-neotetrazolium reductase was observed in basophilic cells of treated individuals. However, in Mytilus edulis, cytochrome P450-linked mixed function oxygenases are regarded mainly as being restricted to hemocytes and, to a much lesser extent, to digestive cells of the digestive tubules and to oocytes (Moore et al. 1978, Moore 1985, Moore 1988).
Similarly, no activity for NADPH-neotetrazolium reductase was observed in basophilic cells of Littorina littorea (Moore et al. 1982) where blood cells display the strongest reactivity. Thus, involvement of basophilic cells in detoxication of products deriving from PHC exposure seems unlikely; their increased numbers may not reflect enhancement of detoxication processes.

In conclusion, exposure to sublethal WAF concentrations of petroleum-derived hydrocarbons results in a significant, dose-dependent increase in VD of basophilic cells of the digestive gland of mussels. These changes could be closely linked to the loss of digestive cells, and to a subsequent wave of basophilic cell proliferation leading to a replacement of the cells lost. Studies are currently being conducted to enable a more rapid quantification of this parameter by automated image analysis.

Acknowledgements. This investigation forms part of the Research Project X-86.041 funded by the Basque Government. The study was partially financied also by the Basque Government through a research fellowship to M.P.C. The authors are specially grateful to Mr P. Larrea and to many other students in our lab for excellent technical assistance.

\section{LITERATURE CITED}

Anderson, J. W., Neff, J. M., Cox, B. A., Tatem, H. E., Hightower, G. M. (1974). Characteristics of dispersions and water-soluble extracts of crude and refined oils and their toxicity to estuarine crustaceans and fish. Mar. Biol. 27 : $75-88$

Axiak, V., George, J. J., Moore, M. N. (1988). Petroleum hydrocarbons in the marine bivalve Venus verrucosa: accumulation and cellular responses. Mar Biol. 97: 225-230

Boylan, D. B., Tripp, B. W (1971). Determination of hydrocarbons in seawater extracts of crude oil and crude oil fractions. Nature, Lond. 230: 44-47

Cajaraville, M. P., Diez, G., Larrea, P., Marigómez, J. A., Angulo, E. (1989a). Planimetric parameters of the digestive tubules of Mytilus edulis: sensitive tools for monitoring petroleum hydrocarbon toxicity? Abstr. int. Symp. on Mussel, Galicia (Spain), p. 15

Cajaraville, M. P., Marigómez, J. A., Angulo, E. (1989b). A stereological survey of lysosomal structure alterations in Littorina littorea exposed to 1-naphthol. Comp. Biochem. Physiol. 93C: 231-237

Cajaraville, M. P., Marigómez, J. A., Angulo, E. (1990). Shortterm toxic effects of 1 -naphthol on the digestive glandgonad complex of the marine prosobranch Littorina littorea (L.): a light microscopic study. Arch. environ. Contam. Toxic. 19: 17-24

Carles, D., Henry, M., Siron, R., Giusti, G. (1986). Induction of ultrastructural alterations in the digestive gland of Mytilus galloprovincialis (Lamarck) by crude oil. In: Giam, C. S., Dou, H. J.-M. (eds.) Strategies and advanced techniques for marine pollution studies: Mediterranean Sea, NATO ASI Series, Vol. G9. Springer-Verlag, Berlin, Heidelberg, p. $461-462$ 
Durfort, M. (1989). Estado morfológico y ultraestructural del hepatopáncreas en relación con la oogénesis. Cell Biol. Rev, S1: 483-489

Harrison, F. L., Berger, R. (1982). Effects of copper on the latency of lysosomal hexosaminidase in the digestive cells of Mytilus edulis. Mar. Biol. 68: 109-116

Langton, R. W. (1975). Synchrony in the digestive diverticula of Mytilus edulis L. J. mar. biol. Ass. U.K. 55: 221-230

Lowe, D. M. (1988). Alterations in the cellular structure of Mytilus edulis resulting from exposure to environmental contaminants under field and experimental conditions. Mar. Ecol. Prog. Ser. 46: 91-100

Lowe, D. M., Moore, M. N., Clarke, K. R. (1981). Effects of oil in the digestive cells in mussels: quantitative alterations in cellular and lysosomal structure. Aquat. Toxicol. 1: 213-226

Marigómez, J. A., Angulo, E., Moya, J. (1986). Copper treatment of the digestive gland of the slug Arion ater L. 2. Morphometrics and histophysiology. Bull. environ. Contam. Toxic. 36: 608-615

Marigómez, J. A., Cajaraville, M. P., Angulo, E. (1990). Histopathology of the digestive gland-gonad complex of the marine prosobranch Littorina littorea exposed to cadmium. Dis. aquat. Org. 9: 229-238

Marigómez, J. A., Vega, M. M., Cajaraville, M. P., Angulo, E. (1989). Quantitative responses of the digestive-lysosomal system of winkles to sublethal concentrations of cadmium. Cell. Mol. Biol. 35: 555-562

Mix, M. C., Sparks, A. K. (1971). Repair of digestive tubule tissue of the pacific oyster, Crassostrea gigas, damaged by ionizing radiation. J. invert. Pathol. 17: 172-177

Moore, M. N. (1980). Cytochemical determination of cellular responses to environmental stressors in marine organisms. Rapp. P.-v. Réun. Cons. perm. int. Explor. Mer 179: 7-15

Moore, M. N. (1985). Cellular responses to pollutants. Mar. Pollut. Bull. 16: 134-139

Moore, M. N. (1988). Cytochemical responses of the lysosomal system and NADPH-ferrihemoprotein reductase in molluscan digestive cells to environmental and experimental exposure to xenobiotics. Mar. Ecol. Prog. Ser. 46: 81-89

Moore, M. N., Lowe, D. M., Fieth, P. E. M. (1978). Lysosomal responses to experimentally injected anthracene in digestive cells of Mytilus edulis. Mar. Biol. 48: 297-302

Moore, M. N., Pipe, R. K., Farrar, S. V (1982). Lysosomal and microsomal responses to environmental factors in Littorina littorea from Sullom Voe. Mar Pollut. Bull. 13: 340-345

Moore, M. N., Pipe, R. K., Farrar, S. V., Thomson, S., Donkin, P. (1987). Lysosomal and microsomal responses to oilderived hydrocarbons in Littorina littorea. In: Capuzzo, J. M., Kester, D. R. (eds.) Oceanic processes in marine pollution, Vol. I. Krieger Publishing Company, Florida, p. 89-96

Responsible Subject Editor: Dr A. K. Sparks, Seattle, Washington, USA
Owen, G. (1970). The fine structure of the digestive tubules of the marine bivalve Cardium edule. Phil. Trans. R. Soc. 258: 245-260

Owen, G. (1972). Lysosomes, peroxisomes and bivalves. Sci. Prog. Oxf. 60: 299-318

Querubin, L. B., Enriquez, G. L. (1989). Light and electron microscopical studies of the hepatopancreas and gonads of Oncomelania hupensis quadrasi. Abstr. 10th International Malacological Congress, Tübingen (FRG), p. 194

Rasmussen, L. P. D., Hage, E., Karlog, O. (1983). Light and electron microscopic studies of the acute and chronic toxic effects of $\mathrm{N}$-nitroso compounds on the marine mussel, Mytilus edulis (L.). II. N-methyl-N-nitro-N-nitrosoguanidine. Aquat. Toxicol. 3: 301-311

Recio, A., Marigómez, J. A., Angulo, E., Moya, J. (1988). Zinc treatment of the digestive gland of the slug Arion ater L. 2. Sublethal effects at the histological level. Bull. environ. Contam. Toxic. 41: 865-871

Rice, S. D., Short, J. W., Karinen, J. F. (1976). Toxicity of Cook Inlet crude oil and No. 2 fuel oil to several Alaskan marine fishes and invertebrates. In: Sources, effects, and sinks of hydrocarbons in the aquatic environment. The American Institute of Biological Sciences, Washington D.C., p. $395-406$

Seed, R. (1969). The ecolagy of Mytilus edulis L. (Lamellibranchiata) on exposed rocky shores. Oecologia 3: 277-316

Sokal, R. R., Rohlf, F. J. (1979). Biometría. Blume, Madrid

Thompson, R. J., Ratcliffe, N. A., Bayne, B. L. (1974). Effects of starvation on structure and function in the digestive gland of the mussel (Mytilus edulis L.). J. mar. Biol. Ass. U.K. 54: $699-712$

Triebskom, R. (1989). The attack of molluscicides on the digestive system of Deroceras reticulatum. Abstr. 10th International Malacological Congress, Tübingen (FRG), p. 252

Tripp, M. R., Fries, C. R., Craven, M. A., Grier, C. E. (1984). Histopathology of Mercenaria mercenaria as an indicator of pollutant stress. Mar. environ. Res. 14: 521-524

Vega, M. M., Marigómez, J. A., Angulo, E. (1989). Quantitative alterations in the structure of the digestive cell of Littorina littorea on exposure to cadmium. Mar Biol. 103: $547-553$

Weibel, E R. (1979). Stereological methods. Vol. I. Academic Press, London

Widdows, J., Moore, M. N., Lowe, D. M. (1984). Sublethal biological effects and short-term recovery of mussels (Mytilus edulis) and winkles (Littorina littorea) following chronic exposure to petroleum hydrocarbon. In: Long term effects of oil on marine benthic communities in enclosures. Norwegian Institute for Water Research/NIVA Technical Report No. 0-82007

Manuscript first received: September 13, 1989

Revised version accepted: July 19, 1990 